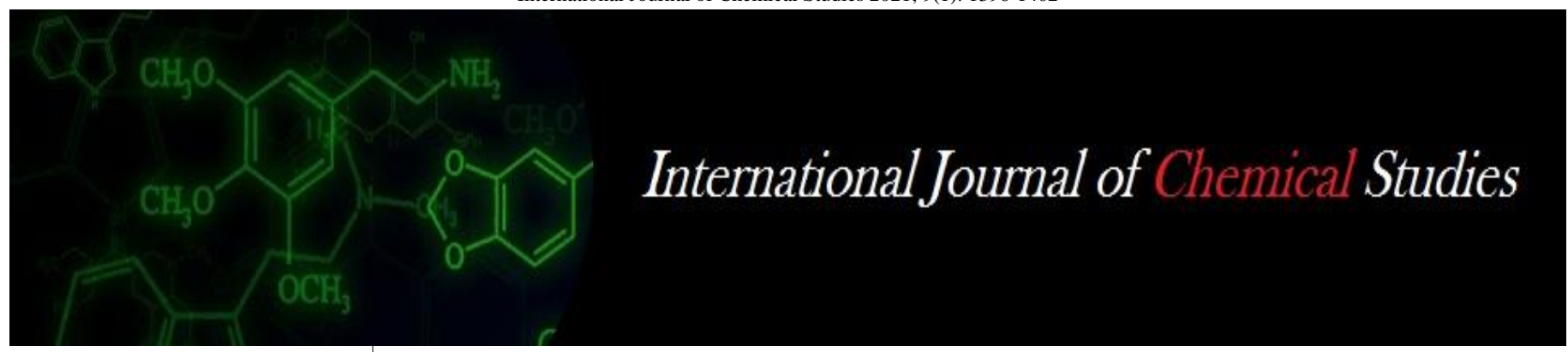

P-ISSN: 2349-8528

E-ISSN: 2321-4902

www.chemijournal.com

IJCS 2021; 9(1): 1396-1402

(C) 2021 IJCS

Received: 19-11-2020

Accepted: 27-12-2020

Uday Sharma

Dr. YS Parmar University of

Horticulture and Forestry,

Nauni, Solan, Himachal

Pradesh, India

Pardeep Kumar

Dr. YS Parmar University of

Horticulture and Forestry,

Nauni, Solan, Himachal

Pradesh, India

Ibajanai Kurbah

Dr. YS Parmar University of

Horticulture and Forestry,

Nauni, Solan, Himachal

Pradesh, India

\section{Anjali Verma}

Dr. YS Parmar University of

Horticulture and Forestry,

Nauni, Solan, Himachal

Pradesh, India

Upender Singh

Dr. YS Parmar University of

Horticulture and Forestry,

Nauni, Solan, Himachal

Pradesh, India

\section{Nutrient management in temperate fruits crops}

\author{
Uday Sharma, Pardeep Kumar, Ibajanai Kurbah, Anjali Verma and \\ Upender Singh
}

DOI: https://doi.org/10.22271/chemi.2021.v9.i1t.11421

\begin{abstract}
All plants require a sufficient supply of essential nutrients to reach their potential, and a deficiency of any single nutrient is enough to limit yields. Supply of adequate quantities of nutrients is essential for sustainable high yield of quality fruits. Unscientific use of chemicals in agriculture has led to several health hazards and environmental problems. To protect our crops and the environment we have to follow sustainable and eco- friendly agriculture, which minimizes the use of harmful and energy intensive inputs and adopts use of organic manures and bio fertilizers. On the other hand, increase in productivity of horticultural produce removes large amounts of essential nutrients from the soil. Without proper management, continuous production of crops reduces nutrient reserves in the soil. Another issue of great concern is the sustainability of soil productivity, as land began to be intensively exhausted to produce higher yields. Overtime, cumulative depletion decreases production, yield and soil fertility and lead to soil degradation. The new approach to farming often referred to as sustainable agriculture, seeks to introduce agricultural practices that are ecofriendly and maintain the long term ecological balance of soil ecosystem. The judicial use of organic inputs with inorganic is considered as the alternative source to meet the nutrient requirement of the crops.
\end{abstract}

Keywords: Nutrient, nutrient management, yield, soil fertility, organics and fertigation

\section{Introduction}

In India, popularly grown temperate fruits are apples, pears, peach, plum, apricot, almond, persimmon, nuts and dry fruits. However, apple is the most important temperate fruit cultivated widely in North-western Himalayan region of the country. Presently, apple occupies 0.16 per cent of total cropped area earning a value of Rs. 3916.59 lakh from the total export of 12.53 thousands MT (Anonymous, 2017) ${ }^{[11]}$. The major producing states are Himachal Pradesh, Jammu and Kashmir, Uttarakhand and Arunachal Pradesh. Himachal Pradesh and J\&K are two leading states contributing about 92 per cent of the total production in the country. India ranks $5^{\text {th }}$ in the world with respect to production, however, the productivity is recorded to be $9.1 \mathrm{t} / \mathrm{ha}$ which is very low compared to countries like China (18.6 t/ha) and USA (35.6 t/ha).

Nutrient management plays a key role for the proper growth and development of fruit trees. These perennial crops need more nutrition than field crops. Adequate nutrient supply is essential for maintaining high productivity, good quality fruit that can be marketed at best price. Most orchards need some external input of manures, fertilizers, amendments to maintain soil fertility for optimum production. It is important to understand the soil fertility status of the land under cultivation. Nutrient management of fruit crops is the most important aspect through which the productivity of the fruits can be increased.

Nutrients are classified into macro and micronutrients based on the quantity required by the plants. Both macro and micronutrients are essentially important for better growth and yield of fruit crops. The micronutrients are involved in various metabolic processes related to photosynthesis and are associated with various enzyme systems. Deficiency of micronutrients has become a major constraint to the growth and production of quality fruit crop. For example, deficiency of boron can be directly observed on fruits such as internal cork, cracking in fruits which ultimately effect quality (Fallahi et al., 2010) ${ }^{[17]}$. The continuous cultivation for many years without adding organic manures and inadequate fertilizer application might have been the causes of nutrient deficiencies in orchards of temperate regions of India. Soil reaction and imbalanced use of fertilizers effects the availability of micronutrients.
Corresponding Author: Anjali Verma

Dr. YS Parmar University of Horticulture and Forestry,

Nauni, Solan, Himachal

Pradesh, India 
Best management practices that can improve supply of nutrients to fruit crops need to be developed for sustaining yield and quality.

\section{Macronutrient management in fruits}

Macronutrients have an important role in governing the growth behaviour of the plants and many times the macronutrient deficiencies have been observed. Apple orchards of Kotkhai tehsil of Shimla district of Himachal Pradesh were surveyed for assessing their nutritional status using soil and leaf analysis. Soil analysis showed that about $15 \%$ orchards were inadequate/low in $\mathrm{N}$ status and all remaining macronutrients were in optimum to high range in all the orchards. The leaf analysis showed medium to high status of all the macronutrients. Soil and leaf $\mathrm{N}$ and $\mathrm{Mg}$ show significantly positive relationship with fruit yield. Available nutrients reflected significantly positive relationship with their respective contents in leaves Awasthi et al. (1998) ${ }^{[1]}$. Casero et al. (2017) ${ }^{[2]}$ observed the macronutrient levels of apple fruits cv. "Golden Smoothee" by monitoring their fruit absorption rates (mg fruit ${ }^{-1}$ day $^{-1}$ ) and accumulation patterns $\left(\mathrm{mg}\right.$ fruit $^{-1}$ ) throughout fruit development. Calcium was chiefly absorbed by the fruit during the first developmental stage, while the greatest absorption rates of other macronutrients occurred later in fruit development (from the end of shoot growth until harvest). From these patterns, it would be desirable to reduce the supply natural calcium $(\mathrm{Ca})$ antagonists, such as potassium $(\mathrm{K})$, ammonium $\left(\mathrm{NH}_{4}{ }^{+}\right)$, and magnesium $(\mathrm{Mg})$, during the first part of fruit development in order to achieve a good $\mathrm{Ca}$ balance with other nutrients and, consequently, an optimum fruit quality. Knowing these nutrient absorption and accumulation patterns is essential for planning optimum nutrient supply and improving their influence on fruit quality. Herencia et al. (2007) ${ }^{[3]}$ revealed that use of organic fertilizer (vegetal compost and green residue of previous crops) resulted in higher soil organic matter, soil $\mathrm{N}$ content, and available $\mathrm{P}$ and $\mathrm{K}$. The nitrate concentration in the edible parts was significantly lower for the crops grown in the organically fertilized plots. This study demonstrated that long- term use of organic compost in greenhouse soil improved soil fertility and produced similar yields and nutrient composition in the edible portion of crops compared with mineral fertilization. Nitrogen $(\mathrm{N})$ and potassium $(\mathrm{K})$ are usually found in higher concentrations than other macronutrients in apple (Malus x domestica Borkh) fruits and are most frequently associated with changes in fruit quality. The effects of $\mathrm{N}$ and $\mathrm{K}$ fertilization on some fruit quality attributes of Fuji apple, were studied by Nava et al. (2008) ${ }^{[4]}$ at São Joaquim, State of Santa Catarina, Brazil, during 2004 and 2005, with $\mathrm{N}$ and $\mathrm{K}$ annual fertilizer rates $(0$, 50,100 , and $200 \mathrm{~kg} \mathrm{ha}^{-1}$ of $\mathrm{N}$ and $\mathrm{K}_{2} \mathrm{O}$ ) replicated in three orchards. Nitrogen fertilization negatively affected fruit color, flesh firmness, and TSS content. These same variables were positively affected by $\mathrm{K}$ fertilization, except for flesh firmness. Von Bennewitz et al. (2015) ${ }^{[5]}$ revealed that the application of decreasing levels of $\mathrm{N}$ fertilization $(100 \mathrm{~kg} \mathrm{~N}$ $\mathrm{ha}^{-1}, 75 \mathrm{~kg} \mathrm{~N} \mathrm{ha}^{-1}, 50 \mathrm{~kg} \mathrm{~N} \mathrm{ha}^{-1}$ and $0 \mathrm{~kg} \mathrm{~N} \mathrm{ha}^{-1}$ ) applied as fossilized red guano ( $50 \%$ of the total amount of $\mathrm{N}$ ) and blood meal $(50 \%$ of the total amount of $\mathrm{N})$ to twelve years old Granny Smith apple, showed low fruit Ca concentrations (2.8 to $3.3 \mathrm{mg} \mathrm{Ca} 100 \mathrm{~g}^{-1} \mathrm{FW}$ ), high levels of $\mathrm{K}$ (118.6 to 130.1 $\mathrm{mg} \mathrm{K} 100 \mathrm{~g}^{-1} \mathrm{FW}$ ) and high values for $\mathrm{K}+\mathrm{Mg} / \mathrm{Ca}(>12)$ and $\mathrm{K} / \mathrm{Ca}(>30)$ ratios. Bitter pit was only detected after 60 days of storage (100 kg N ha-1 tree, 1.1 in a scale 1-4). Nachtigall and Dechen (2006) ${ }^{[6]}$ observed that apple tree leaves and fruits of three cultivars 'Gala', 'Golden Delicious' and 'Fuji' collected weekly and evaluated for fresh and dry matter, fruit diameter and macronutrient $(\mathrm{N}, \mathrm{P}, \mathrm{K}, \mathrm{Ca}$ and $\mathrm{Mg}$ ) and micronutrient $(\mathrm{B}, \mathrm{Cu}, \mathrm{Fe}, \mathrm{Mn}$, and $\mathrm{Zn})$ concentrations, revealed leaf concentrations of $\mathrm{N}, \mathrm{P}, \mathrm{K}, \mathrm{Cu}$, and $\mathrm{B}$ was decreased; $\mathrm{Ca}$ increased; and $\mathrm{Mg}, \mathrm{Fe}, \mathrm{Mn}$, and $\mathrm{Zn}$ did vary significantly along the plant vegetative cycle. In fruits, the initial nutrient concentrations decreased quickly, undergoing slow and continuous decreases and then remaining almost constant until the end of fruit maturation. Banyal et al. (2015) ${ }^{\text {[7] }}$ revealed that peach plants receiving higher (Full dose and 2/3rd dose) doses of $N$ through fertigation were found to have significantly higher vegetative growth, fruit weight, fruit diameter and total yield as compared to lower rates (half and $1 / 3$ rd dose) of fertigation and soil application. Among the cultivars, Early Grande produced fruits with maximum weight $(72.40 \mathrm{~g})$ and length $(46.76 \mathrm{~mm})$, although the total yield was highest (25.22 kg/plant) in Partap owing to the higher number of fruits. The fertilizer use efficiency was highest (118.83 $\mathrm{kg} /$ plant $/ \mathrm{kg}$ ) in plant receiving $1 / 3$ rd dose of $\mathrm{N}$ through drip. Kumar et al. (2017) ${ }^{[8]}$ observed that application of $100 \%$ $\mathrm{NPK}+10 \mathrm{~kg}$ Vermicompost/plant along with biofertilizer inoculation significantly increased leaf area $\left(41.31 \mathrm{~cm}^{2}\right)$, plant height $(227.3 \mathrm{~cm})$, plant spread $(127 \mathrm{~cm} \mathrm{~N}-\mathrm{S}$ and $124.3 \mathrm{~cm} \mathrm{E-}$ $\mathrm{W})$, trunk girth $(60 \mathrm{~mm})$, shoot growth $(43.64 \mathrm{~cm})$, fruit set $(59.41 \%)$, fruit/tree $(97 \mathrm{No})$, fruit weight $(236.3 \mathrm{~g})$, TSS $\left(12.03^{\circ}\right.$ Brix $)$, fruit yield $(22.93 \mathrm{~kg} /$ tree $)$, leaf nitrogen $(2.95 \%)$, phosphorus $(0.52 \%)$ and potassium $(1.54 \%)$ in apple cv. Oregon Spur - II.

\section{Nutrient interactions}

Soil nutrient interaction affects the availability of nutrients to crop plants. Nutrient interaction could be positive or negative and also possible to have no interactions (Retria et al., 2017) [23]. Negative interaction occurs when the supply of one nutrient suppresses the absorption and utilization of other nutrients and this is known as antagonistic effect. Such interaction can be due to similar chemical properties that they compete for their site of adsorption, absorption, transport and function on plant root surfaces or within plant tissues. Such interactions are more common between the nutrients having analogous charge, size, electronic configuration and geometry of coordination e.g. $\mathrm{Ca}^{2+}, \mathrm{Mg}^{2+}, \mathrm{K}^{+}$and $\mathrm{Na}^{+}$. Some few examples are: excess of $\mathrm{P}$ adversely affects the availability of $\mathrm{Zn}, \mathrm{Cu}$ and $\mathrm{Fe}$, excess of lime induces micronutrient deficiency. Positive interaction occurs when nutrients in combination result in a growth response that is greater than the sum of their individual effects and is known as synergistic effect. Such interactions are found between N x P and N x K. There are other factors that control the availability of micronutrients in soil such as soil reaction, organic matter, clay content, soil moisture, temperature, light intensity, soil aeration, microbial activities (Kumar et al., 2016) ${ }^{[41]}$. Better understanding of these nutrient interactions in fruit crops can lead to more efficient management of these nutrients particularly in high density orchards.

\section{Micronutrient management in temperate fruits}

Nutrient deficiency in soil has become a widespread phenomenon that leads to decrease in yield and quality of many horticultural crops. Nutrient deficiency is attributed to several factors such as low organic matter content, soil reaction i.e., alkaline $\mathrm{pH}$ of soils, nutrient interactions etc. Scientific approaches to nutrient management are based on soil testing and plant analysis for examining the nutrient deficiency. 


\section{Foliar application}

Most of nutrients like N, Ca and micronutrients are supplied to fruit crops through foliar application. Foliar application can be done when soil conditions are unfavourable and when smaller quantities of the fertilizer are required. Nutrient fixation, leaching is also reduced when nutrients are applied to the foliage of the plant. The application of the fertilizer at the same time along with insecticide, fungicide, etc., reduces labour costs and machinery costs, thereby reducing the cost of production. Foliar application is a quick method in correcting plant nutrient deficiencies identified through deficiency symptoms, soil test or plant analysis on the plant.

There are numerous studies of nutrient management in fruit crops through foliar spray application. In calcareous soils, foliar application of $\mathrm{Zn}, \mathrm{Cu}$ and $\mathrm{Fe}$ increased primary and final fruit set in pistachio trees and is necessary for obtaining better fruit set, yield and quality (Soliemanzadeh et al., 2013) ${ }^{[24]}$. Similarly, Asaad, $2014^{[12]}$ found that foliar application with 15 ppm Sitofex (CPPU) accompanied by $10 \mathrm{gm} \mathrm{Fe}+7$ $\mathrm{gm} \mathrm{Mn}+10.5 \mathrm{gm} \mathrm{Zn/20L}$ water increased fruit set percentage and yield, improved vegetative growth parameters and leaf micronutrients content (i.e. Fe, $\mathrm{Mn}$ and $\mathrm{Zn}$ ) in "Anna" apple. The combined application of micronutrients ( $\mathrm{Zn}, \mathrm{B}$ and $\mathrm{Fe}$ ) along with other fertilizers was the most efficient and cost effective method to improve the quality and yields of persimmon (Haider et al., 2014) ${ }^{[18]}$. Mixed application of micronutrients i.e. $\mathrm{ZnSO}_{4}$, Borax $\mathrm{FeSO}_{4}$ gave the highest persimmon yield $\left(148.9 \mathrm{~kg} \mathrm{tree}^{-1}\right)$ with an increase of $7.73 \%$ over control.

To improve the chemical and physical parameters of peach fruit, combined application of $\mathrm{Zn}, \mathrm{Cu}, \mathrm{Fe}, \mathrm{Mn}$ and $\mathrm{B}$ were found to give the best result (Ali et al., 2014) ${ }^{[9]}$. Fruit yield was also highest under combined application of the above micronutrients and it was recommended to apply foliar spray twice a year under silt loam, calcareous and alkaline condition of Peshawar soil in order to enhance the efficiency of micronutrients. El-Dahshouri et al., $2017^{[16]}$ reported that different level of concentration foliar application of iron $(\mathrm{Fe})$ nutrient has an important positive effect on the yield and quality parameters of Le Conte pear fruits. Lotze and Hoffman (2014) ${ }^{\text {[21] }}$ reported that as foliar application of calcium (Ca) and boron (B) in Golden Delicious' apple trees on a weekly basis recorded is significantly less sunburn in two consecutive seasons than untreated control fruit, or treatments based on $\mathrm{Ca}$ alone. The effect of combine foliar spray of urea and Agromin (Agromin is a commercial formulation of micronutrients containing mineral elements comprising of optimum proportion of zinc, copper, manganese, boron, molybdenum and magnesium) was studied by Banyal and Banyal (2019) ${ }^{[13]}$ on apple and reported that maximum fruit yield and quality were found in treatment receiving urea @ $1.0 \%$ + Agromin $0.5 \%$ with highest benefit: cost ratio of 2.80. Another study conducted at Anantnag found that the combine foliar application of calcium and boron on apple not only increase yield, but also improve quality that results in significantly higher economic returns (Khan et al. 2019) ${ }^{[20]}$.

\section{Fertilizer application}

Soil application of micronutrient sources separately in the field is difficult. Therefore, most of micronutrients are commonly mixed with fertilizers in both granular and fluid NPK fertilizers. This is a convenient method of application, reduces cost and allows more uniform distribution with conventional application equipment. Intensive cultivation and injudicious use of fertilizers has contributed to widespread deficiency of micronutrients in soil (Behera et al., 2009) ${ }^{[14]}$. Balance fertilization should be in the center of nutrient management for sustaining soil fertility. Soil application combining with foliar spray of both macro and micronutrient resulted in the highest fruit yield and quality in apple, in comparison to the either soil or foliar applications alone (Amiri et al., 2008) ${ }^{[10]}$.

The nutrient use efficiency of most micronutrients in soil is less than $5 \%$ due to lack of synchronization between crop demand and nutrients release (Monreal et al., 2016) ${ }^{[22]}$. Nanotechnologies can play important role through use of nanaoparticles, nanomaterials, nanocapsules to increase micronutrient use efficiency and crop quality. Alternative approach to enhance micronutrients availability can also be achieved by developing nutrient use efficient crop genotype.

\section{Maintaining soil organic matter}

Soil organic matter serves as nutrient source, soil conditioner, substrate for soil microorganisms and it performs many other functions that contribute to soil health and quality. Organic sources of plant nutrients such as farm yard manure, composts, vermicomposts, mulches, green manure, cover crops etc. can be incorporated in nutrient management in orchard. These organic wastes are capable of mobilizing nutrients present in soil and increases the water soluble and exchangeable forms of micronutrients in soil and thereby, increasing uptake of micronutrients. High amount of SOM in soils assists the various reactions of micronutrients resulting in formation of more stable complexes of micronutrient. Soil organic matter binds more $\mathrm{Zn}, \mathrm{Cu}, \mathrm{B}$ and Mo compared to $\mathrm{Fe}$ and $\mathrm{Mn}$ because the former are less sensitive to redox changes (Dhaliwal et al., 2019) ${ }^{[15]}$. Study conducted by Holb and Nagy, $2009{ }^{\text {[19] }}$ found that integrated nutrient management maintain availabilities of micronutrients in whole growing season in apple orchard as compared to organic one. Inclusion of organic manure should be encouraged not only to improve plant nutrition but also for maintaining soil health for a sustainable future.

Kumar et al. $2020^{[25]}$ observed that different organic and inorganic sources of nutrients significantly increased the nutrient status in soil. The organic carbon and the total soluble solids were highest in treatment $\mathrm{T}_{5}$ i.e. $50 \% \mathrm{NPK}+25 \%$ $\mathrm{FYM}+25 \% \mathrm{VC}$ followed by $\mathrm{T}_{4}$ i.e. $50 \% \mathrm{NPK}+50 \% \mathrm{VC}, \mathrm{T}_{3}-$ $50 \% \mathrm{NPK}+50 \% \mathrm{FYM}, \mathrm{T}_{6-}-100 \% \mathrm{VC}, \mathrm{T}_{7}-100 \% \mathrm{FYM}, \mathrm{T}_{2}-$ $100 \% \mathrm{NPK}$ and lowest in $\mathrm{T}_{1}$ (control). The fruit yield significantly increased by $1.17,1.13,1.11,1.08,1.03$ and 1.02 times for the $T_{5}, T_{4}, T_{3}, T_{2}, T_{6}$ and $T_{7}$ compared with the treatment $\mathrm{T}_{1}$. It is concluded that the treatment $\mathrm{T}_{5}$ $(50 \% \mathrm{NPK}+25 \% \mathrm{FYM}+25 \% \mathrm{VC})$ are more effective for fruit yield and improving the nectarine production in temperate areas.

Torshiz et al. (2017) ${ }^{[26]}$ observed lowest fruit cracking $(7.5 \%$, $2.25 \%$ ) as well as fruit infestation with Ectomyelois ceratoniae (Zeller) $(27.5 \%, 25.34 \%)$ in the plants treated with both biofertilizers and humic. Results of leaf analysis revealed that plants treated by a combination of biofertilizer and humic had higher levels of macro and micronutrients compared with untreated plants. Therefore, biofertilizer (azetobarvar, phosphobarvar and potabarvar at 1 liter/tree) in combination with organic fertilizers including: cow manure $(25 \mathrm{~kg} /$ tree $)$, vermicompost $(5 \mathrm{~kg} / \mathrm{tree})$, and granulate humic $(2 \mathrm{~kg} / \mathrm{tree})$, could be used in pomegranate orchards management to improve pomegranate yield, as well as to prevent crop losses resulting from cracking, nutrient deficiency and E. ceratoniae infestation. Dutta et al. (2014) ${ }^{[27]}$ also revealed that the fruits 
of the Pomegranate plants treated with $300 \mathrm{~g}$ nitrogen $+1 \mathrm{~kg}$ neem cake plant ${ }^{-1}$ recorded highest total soluble solids $\left(12.29^{\circ}\right.$ Brix), total sugar $(10.74 \%)$, reducing sugar $(9.78 \%)$, non reducing sugar $(1.09 \%)$ and ascorbic acid (21.93 mg 100 ${ }^{1} \mathrm{~mL}$ of juice). The acidity was also recorded lower $(0.39 \%)$ with this treatment. Kurer et al. (2017) ${ }^{[30]}$ found that $100 \%$ RDN through vermicompost recorded significantly highest vegetative growth (number of shoots/plant, shoot length, plant height and plant canopy spread in N-S and E-W) and $100 \%$ RDN through poultry manure recorded significantly highest number of productive flowers, fruit set and yield. From the results it can be concluded that $100 \%$ RDN through vermicompost and $100 \%$ RDN through poultry manure performed best in improving the growth and yield respectively, of pomegranate cv. Super Bhagwa.

Khachi et al. (2015) ${ }^{[28]}$ found that combination of FYM at 15 $\mathrm{kg} / \mathrm{vine}, \mathrm{GM}, \mathrm{VC}$ at $15 \mathrm{~kg} / \mathrm{vine}, \mathrm{BF}$ at $50 \mathrm{~g} /$ vine and $\mathrm{VW}$ at $2 \mathrm{~kg} / \mathrm{vine}$ significantly improved cropping behavior. This superior combination also resulted in considerably greater amounts of leaf macro-and micronutrients: $\mathrm{N}(2.49 \%), \mathrm{P}$ $(0.26 \%), \mathrm{K}(1.48 \%)$, iron (Fe: $208.0 \mathrm{mg} / \mathrm{kg})$, copper $(\mathrm{Cu}: 17.8$ $\mathrm{mg} / \mathrm{kg}$ ), zinc (Zn: $36.2 \mathrm{mg} / \mathrm{kg}$ ), and manganese (Mn: 88.3 $\mathrm{mg} / \mathrm{kg}$ ), which might be responsible for better cropping behavior, productivity and nutrient profile for sustainable kiwi fruit production. Kumar et al. (2019) ${ }^{[29]}$ found significant effect on fruit quality parameters on full grown (20 years) apricot trees of New Castle cultivar. Maximum fruit length, fruit firmness and fruit breadth, fruit suture, fruit weight and fruit volume was recorded with the application of $50 \% \mathrm{~N}$ $(\mathrm{CN})+50 \% \mathrm{~N}$ (Urea) + Azotobacter + PSB + Vermicompost. While, maximum TSS, TSS/acid ratio, total sugars (11.45\%), reducing sugars and minimum titratable acidity was recorded under $50 \% \mathrm{~N}(\mathrm{CN})+50 \% \mathrm{~N}($ Urea $)+$ Azotobacter + PSB + FYM. Also, maximum yield was recorded with application of $50 \% \mathrm{~N}(\mathrm{CN})+50 \% \mathrm{~N}$ (Urea) + Azotobacter + PSB + Vermicompost.

Soni et al. (2018) [31] revealed that the treatment $50 \%$ Vermicompost $+50 \%$ Poultry Manure + Azotobacter was found to be the best among the various treatments in Strawberry (Fragaria x ananassa Duch) cv. Sweet Charlie" and recorded maximum plant height $(19.61 \mathrm{~cm})$, number of leaves (21.11), plant spread (24.54), number of flowers $\left(30.41\right.$ plant $\left.^{-1}\right)$, number of fruit (12.41 plant $\left.^{-1}\right)$, fruit length $(3.70 \mathrm{~cm})$, fruit width $(3.20 \mathrm{~cm})$, fruit weight $(11.83 \mathrm{~g})$. The treatment also recorded the maximum fruit yield $(144.77 \mathrm{~g}$ plant ${ }^{-1}, 2.32 \mathrm{~kg} \mathrm{plot}^{-1}$, and $7.72 \mathrm{t} \mathrm{ha}^{-1}$ ) which was followed by $50 \%$ Vermicompost $+50 \%$ FYM + Azotobacter. Rai et al. (2012) ${ }^{[32]}$ found that application of $40 \mathrm{~kg}$ vermicompost per tree significantly increased the yield and yield attributing characters of pear cultivar Gola. The quality parameters TSS, acidity, ascorbic acid content and reducing sugar content were also found best with the application of $40 \mathrm{~kg}$ vermicompost/tree. Sharma et al. (2016) ${ }^{[33]}$ revealed that the highest soil organic carbon $(0.72 \%)$ was obtained with the treatment comprising (Azotobacter $+100 \% \mathrm{~N}$ poultry manure). Soil N and P (271.36 and $19.86 \mathrm{~kg} / \mathrm{ha}), \mathrm{Ca}$ and $\mathrm{Mg}$ (7.12 and $2.82 \mathrm{meq} \mathrm{100/g} \mathrm{soil),} \mathrm{respectively,} \mathrm{were} \mathrm{recorded}$ maximum with the treatment comprising Azotobacter $+50 \%$ $\mathrm{N}$ poultry manure $+50 \% \mathrm{~N}$ urea. The same treatment also showed highest leaf $\mathrm{N}$ and $\mathrm{P}$ (1.78 and $0.16 \%), \mathrm{Ca}$ and $\mathrm{Mg}$ ( 2.09 and $0.91 \%$ ) contents, respectively, on dry weight basis.

\section{Fertigation in temperate fruits}

Fertigation offers increased flexibility in managing orchard nutrition programs because of the potential for more closely synchronizing nutrient application with plant demand (Haynes, 1985) ${ }^{[36]}$. There is a need, however, to assess effectiveness of any new fertilization strategy relative to traditional methods. The crop wise studies on fertigation have been reviewed below:

Wojcik and Treder (2006) ${ }^{[42]}$ carried out studies in 2001 to 2003 on the effect of boron fertigation on mature Jonagold'apple (Malus domestica Borkh.) trees (M.26 EMLA) planted at high density spacing of $4 \times 2.5 \mathrm{~m}$ on a sandy loam soil with low boron (B) availability. The trees were drip fertigated with boron at rates of $0.5,1$, or $1.5 \mathrm{~g}^{\text {tree }}$ ${ }^{1}$ over 4weeks at 3-day intervals beginning at the stage of bud break. Plants that did not receive boron via drip irrigation system served as a control. Drip boron fertigation effectively increased water-soluble boron concentrations in the soil and the status of this microelement in leaves of current season shoots. However, the boron fertigation had no effect on tree vigor. In 2 out of 3 years, the drip boron fertigation improved flower boron status, fruit set, and yield. The efficiency of the drip boron fertigation was not influenced by boron rate. In all growing seasons, the drip boron fertigation increased boron level and a soluble solids concentration in the fruit flesh, but had no effect on mean fruit weight, color, titratable acidity, and fruit firmness. It was concluded that on coarse-textured soils with low boron availability, the drip boron fertigation of mature apple trees in high-density orchards can be recommended from the stage of bud burst to petal fall at a rate of $0.5 \mathrm{~g}$ tree ${ }^{-1}$. Banyal and Rehalia (2010) ${ }^{[34]}$ conducted the experiment on six years old apple plants of cultivars Scarlet Gala and Red Fuji grafted on three clonal rootstocks viz., EMLA-106, EMLA-7 and EMLA-111. The irrigation treatments comprised of application of water at $100 \% \mathrm{ET}_{\mathrm{c}}$, $80 \% \quad \mathrm{ET}_{\mathrm{c}}, \quad 60 \% \quad \mathrm{ET}_{\mathrm{c}}, \quad 40 \% \quad \mathrm{ET}_{\mathrm{c}}$ through drip or $100 \%$ $\mathrm{ET}_{\mathrm{c}}$ through basin (control). Fruit firmness, TSS, titratable acidity, reducing sugars, total sugar and non-reducing sugars content decreased with increase in the volume applied through drip. Various physical quality parameters were significantly improved by drip irrigation over basin irrigation. The fruits of both the varieties had maximum length, diameter and weight on the rootstock EMLA-106. Drip irrigation at a volume of $40 \% \mathrm{ET}_{\mathrm{c}}$ was found to have maximum water use efficiency (WUE).

Raina et al., (2013) ${ }^{[41]}$ found that different fertigation levels treatment comprising $(80 \%$ of RD + irrigation at $80 \%$ ETc through drip with mulch $\mathrm{F}_{3} \mathrm{M}_{1}$ ) registered statistically comparable growth and yield attributes, which may be attributed to combined effects of drip fertigation in terms of nutrient availability and better moderation of soil hydrothermal regimes under mulch, which resulted in more congenial condition for water and nutrient uptake. Under this treatment, only $80 \%$ of crop water requirement was met hence, moisture conservation by mulch might have met the crop ET, thereby resulting in greater growth and yield advantages. Drip fertigation significantly influenced the Fertilizer-use efficiency (FUE) over conventional fertilization. This was due to better availability and uptake of water and nutrients under fertigation throughout the growing season, which resulted in greater tree vigor and fruit yield and consequently greater FUE. Fertigation resulted in $35 \%$ greater growth and yield over conventional fertilization with irrigations besides saving $25 \%$ in irrigation water. Kumar et al., (2016) ${ }^{[40]}$ recorded that fertigation significantly increased growth parameters over conventional methods. Fruit yield was significantly higher under fertigation $\left(13.7 \mathrm{t} \mathrm{ha}^{-1}\right)$ over conventional fertilizer application with drip $\left(11.6 \mathrm{t}\right.$ ha $\left.{ }^{-1}\right)$, 
surface irrigation (10.6 $\left.\mathrm{t} \mathrm{ha}^{-1}\right)$ and under rainfed $\left(8.6 \mathrm{t} \mathrm{ha}^{-1}\right)$. Higher fruit yield under fertigation resulted from higher tree canopy volume, number of fruits per plant, fruit weight/volume, and higher FUE. Fertigation maintained higher available nitrogen $(\mathrm{N})$ and potassium $(\mathrm{K})$ content in 0 $30 \mathrm{~cm}$ soil layers whereas, available phosphorus (P) was higher in $0-20 \mathrm{~cm}$ soil depths in all the treatments. Fertigation with 80 percent RD of NPK was found to be equally promising as the recommended 100 percent dose. In addition to higher productivity, fertigation with 80 percent RD of NPK resulted in 20 percent fertilizer savings over drip irrigation and 20 percent fertilizer besides 40 percent water savings over surface irrigation. It is, therefore, concluded that treatment $\mathrm{T}_{2}$ ( $80 \%$ of recommended NPK) is the most suitable fertigation level for apple orchards of North Western Himalayan region. Banyal et al, (2016) ${ }^{[35]}$ observed that plants receiving higher (Full dose and 2/3rd dose) doses of $\mathrm{N}$ through fertigation were found to have significantly higher vegetative growth, fruit weight, fruit diameter and total yield as compared to lower rates (half and 1/3rd dose) of fertigation and soil application. Among the cultivars, Early Grande produced fruits with maximum weight $(72.40 \mathrm{~g})$ and length $(46.76 \mathrm{~mm})$, although the total yield was highest (25.22 kg/plant) in Partap owing to the higher number of fruits. The fertilizer use efficiency was highest $(118.83 \mathrm{~kg} / \mathrm{plant} / \mathrm{kg})$ in treatment $\mathrm{T}_{4}(1 / 3 \mathrm{rd}$ dose of $\mathrm{N}$ through drip). Therefore, the dose of $\mathrm{N}$ application in peach trees can be reduced to $2 / 3^{\text {rd }}$ of its standard rate when applied through drip without any significant reduction in yield and quality.

Kachwaya and Chandel (2015) ${ }^{\text {[37] }}$ revealed that fertigation with recommended dose of NPK in strawberry (Fragaria $\times$ ananassa Duch.) var. Chandler gave significantly higher plant height $(24.23 \mathrm{~cm})$, leaf area $\left(129.20 \mathrm{~cm}^{2}\right)$, fruit yield $(35.64$ tonnes/ha) as compared to fertigation with $1 / 2$ and $1 / 3$ of recommended dose of NPK and soil fertilization, but was found at par with $3 / 4$ recommended dose of NPK fertigation treatment. The maximum fruit length $(42.49 \mathrm{~mm})$, fruit breadth $(31.74 \mathrm{~mm})$ and fruit weight $(19.87 \mathrm{~g})$ was also recorded in fertigation with full recommended dose of NPK. The values of TSS $(9.88 \mathrm{oB})$, total sugar $(9.44 \%)$, anthocyanin (0.249 OD) and ascorbic acid (53.39 $\mathrm{mg} / 100 \mathrm{~g})$ was significantly higher in fertigation with recommended dose of NPK treatment as compared to lower levels of fertigation and soil fertilization. The plants fertigated with full and $3 / 4$ recommended dose of NPK also had higher leaf nutrients content. Fertigation with $3 / 4$ of recommended dose of NPK registered 60 per cent higher fertilizer use efficiency over soil fertilization with full recommended dose of NPK and also resulted in 25 per cent saving of fertilizers without any adverse effect on growth, yield and fruit quality.

Kumar and Ahmed (2014) ${ }^{[38]}$ observed maximum tree height $(3.21 \mathrm{~m}$ and $3.56 \mathrm{~m})$, nut weight $(2.73 \mathrm{~g}$ and $1.94 \mathrm{~g})$, nut yield $(2.41 \mathrm{~kg} /$ tree and $5.98 \mathrm{~kg} /$ tree; $2.67 \mathrm{t} / \mathrm{ha}$ and $6.64 \mathrm{t} / \mathrm{ha})$, and leaf nutrient content $(2.34$ and $2.38 \% \mathrm{~N} ; 0.14$ and $0.17 \% \mathrm{P}$; 1.37 and $1.41 \% \mathrm{~K}$ ) in treatment $75 \% \mathrm{RDF}$ through fertigation (split application), treatment, whereas the highest crosssectional area of main trunk, primary, secondary, and tertiary branches (72.67 and $90.28 \mathrm{~cm}^{2} ; 16.75$ and $24.26 \mathrm{~cm}^{2} ; 3.83$ and $7.49 \mathrm{~cm}^{2} ; 0.47$ and $\left.1.23 \mathrm{~cm}^{2}\right)$, canopy volume $(7.15$ and $\left.8.11 \mathrm{~m}^{3}\right)$, and fruit number (990 and 3083/tree) were recorded with $100 \%$ RDF through fertigations in almond variety Waris. Kumar and Singh (2018) ${ }^{\text {[31] }}$ also revealed that maximum plant height $(3.67 \mathrm{~m})$, cross-sectional area of main trunk $\left(101.22 \mathrm{~cm}^{2}\right)$, primary, secondary and tertiary branches $(20.51,6.66 \mathrm{~cm}$ and $1.97 \mathrm{~cm})$, canopy volume $(8.21 \mathrm{~m})$ were obtained with $75 \%$ RDF through fertigation (split application of $\mathrm{N}$ : $\mathrm{K}$ in the ratio of $2 / 3 \mathrm{~N}: 1 / 3 \mathrm{~K}$ at nut set to nut development and $1 / 3 \mathrm{~N}: 2 / 3 \mathrm{~K}$ at kernel filling to maturation stage $\left(\mathrm{T}_{4}\right)$.

\section{Conclusion}

Nutrient management is the process of managing the amount, source, timing and method of nutrient application with the goal of optimizing productivity and minimizing nutrient losses. It includes; Nutrient requirements, nutrient supply sources, tree nutrient status and management strategies. Good management of nutrients requires that supply should match the demand, in terms of amount, timing and retention in the root zone. Many approaches have been followed for optimum nutrient management in fruit plants, so that we can increase both the nutrient use efficiency as well as the fruit quality. Fertigation allows such flexibility in the timing and precision of nutrient supply. It gives greater $\mathrm{P}$ and $\mathrm{K}$ mobility than broadcasting. Improving nutrient use efficiency is very essential both from economic as well as environmental point of view. Building up of soil organic matter should be enhanced as it supports diverse microbial community and reduces nutrient leaching. Incorporation of organic fertilizers is a common practice to improve the yield of many fruit crops. It also limits chemical intervention and finally minimizes the negative impact on the wider environment. Thus, for the production of quality fruits and for optimum utilization of available resources, we have to look for different alternatives including integrated nutrient management as well as micronutrient management, so that our goal of sustainable production is achieved.

\section{References}

1. Awasthi RP, Bhutani VP, Sharma JC, Kaith NS. Mineral nutrient status of apple orchards in Shimla district of Himachal Pradesh. Indian Journal of Horticulture 1998;55(4):314-322.

2. Casero T, Torres E, Alegre S, Racasens I. Macronutrient accumulation dynamics in apple fruits. Journal of Plant Nutrition 2017;40(17):2468-2476.

3. Herencia JF, Ruiz Porras JC, Melero S, Garcia Galavis PA, Morillo E, Maqueda C. Comparison between organic and mineral fertilization for soil fertility levels, crop macronutrient concentration and yield. Agronomy Journal 2007;99(4):973-983.

4. Nava G, Dechen AR, Nachtigall GR. Nitrogen and potassium fertilization affect apple fruit quality in Southern Brazil. Communication in Soil Science and Plant Analysis 2008;39(1-2):96-107.

5. Von Bennewitz E, Cooper T, Losak T, Hlusek J, Benavides MC. Effects of decreasing levels of $\mathrm{N}$ amendments on organic granny smith apple trees. Journal of Soil Science and Plant Nutrition 2015;15(4):979-990.

6. Nachtigall GR, Dechen AR. Seasonality of nutrients in leaves and fruits of apple trees. Scientia Agricola 2006;63(5):493-501.

7. Banyal SK, Sharma D, Jarial K. Effect of nitrogen fertigation on yield and fruit quality of low chilling peaches under subtropical conditions of Himachal Pradesh. Indian Journal of Horticulture 2015;72(4):457460.

8. Kumar A, Sharma N, Sharma CL, Singh G. Studies on nutrient management in apple cv. Oregon Spur-II under the cold desert region of Himachal Pradesh in India. 
Indian Journal of Agricultural Research 2017;51(2):161166.

9. Ali A, Perveen S, Shah SNM, Zhang Z, Wahid F, Shah $\mathrm{M}$ et al. Effect of Foliar Application of Micronutrients on Fruit Quality of Peach. American Journal of Plant Sciences 2014;5:1258-1264.

10. Amiri Mohammad E, Esmaeil Fallahi, Ahmad Golchin. Influence of foliar and ground fertilization on yield, fruit quality and soil, leaf, and fruit mineral nutrients in apple. Journal of Plant Nutrition 2008;31(3):515-525. DOI: $10.1080 / 01904160801895035$

11. Anonymous. Horticultural statistics at a glance. Hortciculture Statistics Division. Department of Agriculture, Cooperationand Farmers Welfare 2017.

12. Asaad A. The influence of spraying sitofex, iron, manganese and zinc on Anna apple trees planted on new reclaimed calcareous land Samia. Life Science Journal 2014;(11):1-8.

13. Banyal SK, Banyal AK. Foliar fertilization for enhancing yield and fruit quality of Apple under rain-fed conditions of Mid-Himalayas. Journal of Krishi Vigyan 2019;8(1):137-141.

14. Behera SK, Singh MV, Lakaria BL. Micronutrient deficiencies in Indian soils and their amelioration through fertilization. Indian Farming 2009, 28-30.

15. Dhaliwal SS, Naresh RK, Mandal A, Singh R, Dhaliwal MK. Dynamics and transformations of micronutrients in agricultural soils as influenced by organic matter buildup: A review. Environmental and Sustainability Indicators 2019;1-2:100007.

16. El-Dahshouri MF, Hamouda HA, Hafez OM, Khafagy SA. Enhancing le-conte pear trees performance by foliar spray with different Iron concentrations. Agricultural Engineering International: CIGR Journal Special issue: 2017, 201-210.

17. Fallahi E, Fallahi B, Neilsen GH, Neilsen D, Peryea FJ. Effects of mineral nutrition on fruit quality and nutritional disorders in apples. Acta Horticulturae 2010;868:49-60.

18. Haider Ali, Shah AH, Naeem M, Khan J, Majid A, Iqbal $\mathrm{Z}$ et al. Effect of foliar application of micronutrients on persimmon fruit quality and yield. International Journal of Biosciences 2014;4(7):82-88.

19. Holb IJ, Nagy PT. Availability of Calcium, Magnesium, Sulfur, Copper, Zinc, and Manganese in the plant-soil system of integrated and organic apple orchards. Communications in Soil Science and Plant Analysis 2009;40(1-6):682-693.

20. Khan Ishtiyaq A, Aasima Rafiq, Ganie SA. Effect of different sources and concentrations of pre-harvest calcium and boron sprays on the quality and yield of Apple (Malus $x$ domestica Borkh) Journal of Krishi Vigyan 2019;7(2):78-82.

21. Lotze E, Hoffman EW. Foliar application of calcium plus boron reduces the incidence of sunburn in 'Golden Delicious' apple. The Journal of Horticultural Science and Biotechnology 2014;89(6):607-612.

22. Monreal CM, DeRosa M, Mallubhotla SC, Bindraban PS, Dimpka C. Nanotechnologies for increasing the crop use efficiency of fertilizer-micronutrients. Biology and Fertility of Soils 2016;52:423-427.

23. Rietra RPJJ, Heinen M, Chistian OD, Bindraban PS. Effects of nutrient antagonism and synergism on yield and fertilizer use efficiency. Communications in Soil Science and Plant Analysis 2017;48(16):1895-1920.
24. Soliemanzadeh Akbar, Vahid Mozafari, Ahmad Tajabadi Pour, Abdolreza Akhgar. Effect of $\mathrm{Zn}, \mathrm{Cu}$ and Fe foliar application on fruit set and some quality and quantity characteristics of Pistachio trees. South Western Journal of Horticulture, Biology and Environment 2013;4(1):1934.

25. Kumar M, Jamwal M, Kotwal N, Sharma R, Choudhary SK, Kumar V et al. Effect of integrated use of organic and inorganic sources of nutrients on nectarine crop cv. Silver king under temperate condition. International Journal of Chemical Studies 2020;8(1):287-291.

26. Torshiz AO, Goldansaz SH, Motesharezadeh B, Sarcheshmeh MAA, Zarei A. Effect of organic and biological fertilizers on pomegranate trees: yield, cracking, sunburning and infestation to pomegranate fruit moth Ectomyelois ceratoniae (Lepidoptera: Pyralidae). Journal of Crop Protection 2017;6(3):327-340.

27. Dutta SKR, Takawale PV, Chatterjee R, Hnamte V. Yield and quality of pomegranate as influenced by organic and inorganic nutrients. The Bioscan 2014;9(2):617-620.

28. Khachi B, Sharma SD, Ghumare V, Kumar P, Mir M. Study on comparative efficacy of bio-organic nutrients on plant growth, leaf nutrient contents and fruit quality attributes of kiwi fruit Journal of Applied and Natural Science 2015;7(1):175-181.

29. Kumar A, Sharma DD, Sharma DP, Shylla B, Sharma S. Effect of integrated nutrient sources on fruit quality of apricot (Prunus armeniaca L.) under mid hill conditions of Himachal Pradesh. Journal of Pharmacognosy and Phytochemistry 2019;8(2):1120-1123.

30. Kurer SB, Patil DR, Gandolkar K, Mesta RK, Nagaraj MS, Nadaf AM et al. Response of pomegranate to different organic manures under northern dry zone of karnataka, India. International Journal of Current Microbiology \& Applied Sciences 2017;6(11):86-90.

31. Soni S, Kanawjia A, Chaurasiya R, Chauhan PS, Kumar R, Dubey S. Effect of organic manure and biofertilizers on growth, yield and quality of strawberry (Fragaria $X$ ananassa Duch) cv. Sweet Charlie Journal of Pharmacognosy and Phytochemistry 2018;2:128-132.

32. Rai PN, Singh PN, Binayak C. Effect of different sources of organic manures on yield and quality of low - chill pear (Pyrus pyrifolia) cv. Gola. Progressive Horticulture 2012;41(1):103-106.

33. Sharma A, Wali VK, Bakshi P, Sharma V, Sharma V, Bakshi $\mathrm{M}$ et al. Impact of poultry manure on fruit quality attributes and nutrient status of guava (Psidium guajava.) cv. L 49 plant. Indian Journal of Agricultural Sciences 2016;86(4):533-40.

34. Banyal SK, Rehalia AS. Fruit quality and water use efficiency as affected by various drip irrigation levels and rootstocks in apple. Environment and Ecology 2010;28(1A):413-417.

35. Banyal KS, Sharma D, Jarial K. Effect of nitrogen fertigation on yield and fruit quality of low chilling peaches under subtropical conditions of Himachal Pradesh. Indian Journal of Horticulture 2016;72(4):457460.

36. Haynes RJ. Principles of fertilizer use for trickle irrigated crops. Fertilizer Research 1985;6:235-255.

37. Kachwaya SD, Chandel. Effect of fertigation on growth, yield, fruit quality and leaf nutrients content of strawberry (Fragaria $\times$ ananassa) cv Chandler. Indian Journal of Agricultural Sciences 2015;85:1319-1323. 
38. Kumar D, Ahmed N. Response of Nitrogen and Potassium fertigation to Waris almond (Prunus dulcis) under Northwestern Himalayan Region of India. Scientific World Journal 2014, 22 doi: $10.1155 / 2014 / 1413282014$

39. Kumar D, Singh DB. Effect of fertigation on growth, yield and quality of almond under Kashmir conditions. Indian Journal of Horticulture 2018;75:197-20.

40. Kumar P, Suman S, Spehia SR, Kumar V, Kaith NS. Studies on methods and rate of fertilizer application in apple under mulch in North Western Himalayas. Journal of Plant Nutrition 2016;39(2):219-226.

41. Raina JN, Shashi Suman, Kumar P, Spehia RS. Effect of drip fertigation with and without mulch on soil hydrothermal regimes, growth, yield and quality of apple (Malus domestica Borkh.). Communication in Soil Science and Plant Analysis 2013;44:2560-2570.

42. Wojcik Pand, Treder W. Effect of drip boron fertigation on yield and fruit quality in a high-density apple orchard. Journal of Plant Nutrition 2006;29:2199-2213. 